University of Nebraska - Lincoln

DigitalCommons@University of Nebraska - Lincoln

Proceedings of the North American Prairie

Conferences

North American Prairie Conference

2004

\title{
The Prairie-Wetland Vegetation Continuum in the Chicago Region of Northeastern Illinois
}

Martin Bowles

The Morton Arboretum

Michael Jones

Christopher B. Burke Engineering, Ltd.

Follow this and additional works at: https://digitalcommons.unl.edu/napcproceedings

Part of the International and Area Studies Commons

Bowles, Martin and Jones, Michael, "The Prairie-Wetland Vegetation Continuum in the Chicago Region of Northeastern Illinois" (2004). Proceedings of the North American Prairie Conferences. 64.

https://digitalcommons.unl.edu/napcproceedings/64

This Article is brought to you for free and open access by the North American Prairie Conference at DigitalCommons@University of Nebraska - Lincoln. It has been accepted for inclusion in Proceedings of the North American Prairie Conferences by an authorized administrator of DigitalCommons@University of Nebraska - Lincoln. 


\title{
The Prairie-Wetland Vegetation Continuum in the Chicago Region of Northeastern Illinois
}

\author{
by Marlin Bowles ${ }^{1}$ and Michael Jones ${ }^{2}$ \\ ${ }^{1}$ The Morton Arboretum, Route 53, Lisle, IL 60532 \\ ${ }^{2}$ Christopher B. Burke Engineering, Ltd., Rosemont, IL 60018
}

\begin{abstract}
We conducted a floristic ordination and gradient analysis of plant communities extending from prairie through graminoid-dominated wetlands in the Chicago region of northeastern Illinois. Data represented about 450 species from 103 stands sampled across a gradient of six soil moisture classes ranging from dry to hydric, and included sand, gravel, dolomite and loam prairies, as well as fen, sedge meadow, floating mat, marsh, and bog. As found in other midwestern grassland studies, vegetation aligned most strongly along a soil moisture gradient, with individualistic species distributions forming a hierarchical continuum, and lower species richness at the dry and wet extremes of the moisture gradient. Most species were infrequent, with about $70 \%$ occurring at less than $20 \%$ frequency and present in less than five communities. Species that were more frequent within communities were also more widespread among communities, fitting the niche-based model of species distribution. Moreover, less than $20 \%$ of all species sampled were significant indicators of soil moisture gradient classes, with most representing mesic and hydric habitats. Dominant prairie grasses extended from dry to wet habitats, merging with wetland species in graminoid fen, calcareous seep and sedge meadow habitats. Hydric habitat, represented by calcareous floating mat, marsh and bog, had fewer dominant prairie species and was dominated by a wetland flora. These results provide compositional and structural models for managing and restoring vegetation across the prairie-wetland vegetation gradient of the Chicago region.
\end{abstract}

Keywords: Chicago region flora, floristic ordination, gradient analysis, prairies, wetlands

\section{Introduction}

The eastern tallgrass prairie and its associated wetlands are one of North America's most highly fragmented ecosystems (Robertson and Schwartz 1994, Samson and Knopf 1994). This vegetation constituted about $80 \%$ of the pre-European settlement landscape of the Chicago region of northeastern Illinois, covering about $1,598,090$ acres $(647,000$ hectares) (e.g., McBride and Bowles 2001). Today, less than $0.2 \%$ of this vegetation remains in high-quality condition (White 1978), and there is little specific information available on the extent to which it intergrades along an edaphic gradient ranging from dry to hydric. This information is important because the great interest in managing and restoring tallgrass prairie and wetlands in the Chicago region (Betz 1986, Packard and Mutel 1997, Betz and others 2000) requires knowledge of how species are distributed across environmental gradients.

Soil moisture, as controlled by drainage, is considered the primary environmental factor affecting the distribution of prairie vegetation. Curtis (1959) used a compositional index based on indicator species for different drainage types to describe the distribution of Wisconsin prairie species along a one-dimensional soil moisture gradient ranging from dry to wet. Dix and Smeins (1967) also used soil moisture as the primary ecological gradient for a landscape-scale analysis of North Dakota prairie vegetation. However, soil texture, degree of internal drainage, and soil depth also have impor- tant secondary effects on species distribution (Whitford 1958, Nelson and Anderson 1982). For example, White and GlennLewin (1984) found a multidimensional relationship among Iowa prairie stands based on direct gradient analysis of species distribution in relation to soil drainage and textural differences. Faber-Langendoen and Maycock (1994) found a similar relationship across prairie vegetation gradients in Ontario. In Illinois, Corbett and Anderson (2001) also demonstrated that soil texture and topographic position interact with soil moisture to affect the distribution of prairie vegetation.

In addition to expected edaphic effects on vegetation, multiple models have been applied to the landscape scale distribution of prairie species. Using data from Betz and Lamp (1989), Collins and Glenn (1991) demonstrated that regional prairie species distribution fits the niche-based species distribution model of Brown (1984). In this model, common species (i.e., occurring at high frequencies within communities) also have broad habitat niches, occurring across multiple communities. Conversely, rare species that occur at low frequencies also tend to have more narrow niches, occurring across fewer communities. Plant species are also expected to have individualistic distributions that form a continuum across environmental gradients (Gleason 1926). Based on this model, plant communities can be described based on overlapping distributions of dominant species, but no species will 
have identical patterns (Curtis 1959). With a broad gradient, this pattern also may be nested and hierarchical (Collins and others 1993). A third model can be developed based on the expected distribution of species richness, which usually peaks at intermediate resource levels (Mittlebach and others 2001). In accordance, species richness in Midwest prairies has been found to be unimodal across a landscape soil moisture gradient, with lower richness in dry or wet habitat extremes (Curtis 1959, Bliss and Cox 1964, Dix and Smeins 1967, Crist and Glen-Lewin 1978).

In this paper, we use historic data to conduct a floristic gradient analysis in relation to soil moisture drainage classes and substrate types for prairie and graminoid wetland vegetation of the Chicago region of northeastern Illinois. We sought to determine how plant species and communities are distributed across a landscape soil moisture gradient, and to describe the ecological distribution of dominant prairie and graminoid wetland vegetation in the Chicago region. We also determined how species and species richness are distributed across this ecological gradient in relation to the niche-based, continuum and unimodal models, and the extent to which indicator species could be identified for different habitats based on moisture gradient categories.

\section{Study Area}

The surficial geology of the Chicago region of Illinois represents Woodfordian-aged glacial material, which was deposited in the last 20,000 years. The northern, western and southern portions of the region are primarily glacial drift represented as end moraines, till plains and outwash, while the east central part of the region occupies the former bed of glacial Lake Chicago, formed about 14,000 years ago after the retreat of the last glacier (Willman 1971). Predominant substrates include finetextured silt- and clay-loams developed from glacial till and lake bed deposits; sands in glacial outwash, lake plain deposits and beach ridges; coarse-textured gravels in kames, eskers and valley train deposits; and dolomite bedrock exposed along the major river valleys. Soil chemistry and fertility vary across these habitats (Fehrenbacher and others 1984). Fine-textured prairie soils tend to be neutral in $\mathrm{pH}$, with about $10 \%$ organic matter; sand soils are usually acidic with less organic content, but become alkaline near Lake Michigan; gravel and dolomite soils are usually alkaline and calcareous but with low organic matter (Bowles and others 2005a). Wetlands range from acid to alkaline, depending upon groundwater characteristics, with up to $50 \%$ or more organic matter in bogs and fens and over 20,000 ppm Calcium in strongly calcareous sites (Bowles and others 2005b).

The Chicago region is located along the northeastern boundary of the "prairie peninsula," a biogeographic zone of North America located at the east edge of the rain shadow of the Rocky Mountains (Transeau 1935). This eastern extension of prairie has cold winters and warm, humid summers that are characterized by unpredictable precipitation and occasionally severe summer drought (Weaver 1954). These periodic droughts acted in concert with frequent lightningand Indian-set prairie fires to maintain tallgrass prairie and savanna in a region where annual rainfall is capable of supporting forest development (Gleason 1913, Curtis 1959, Anderson 1990, Anderson and Bowles 1999).

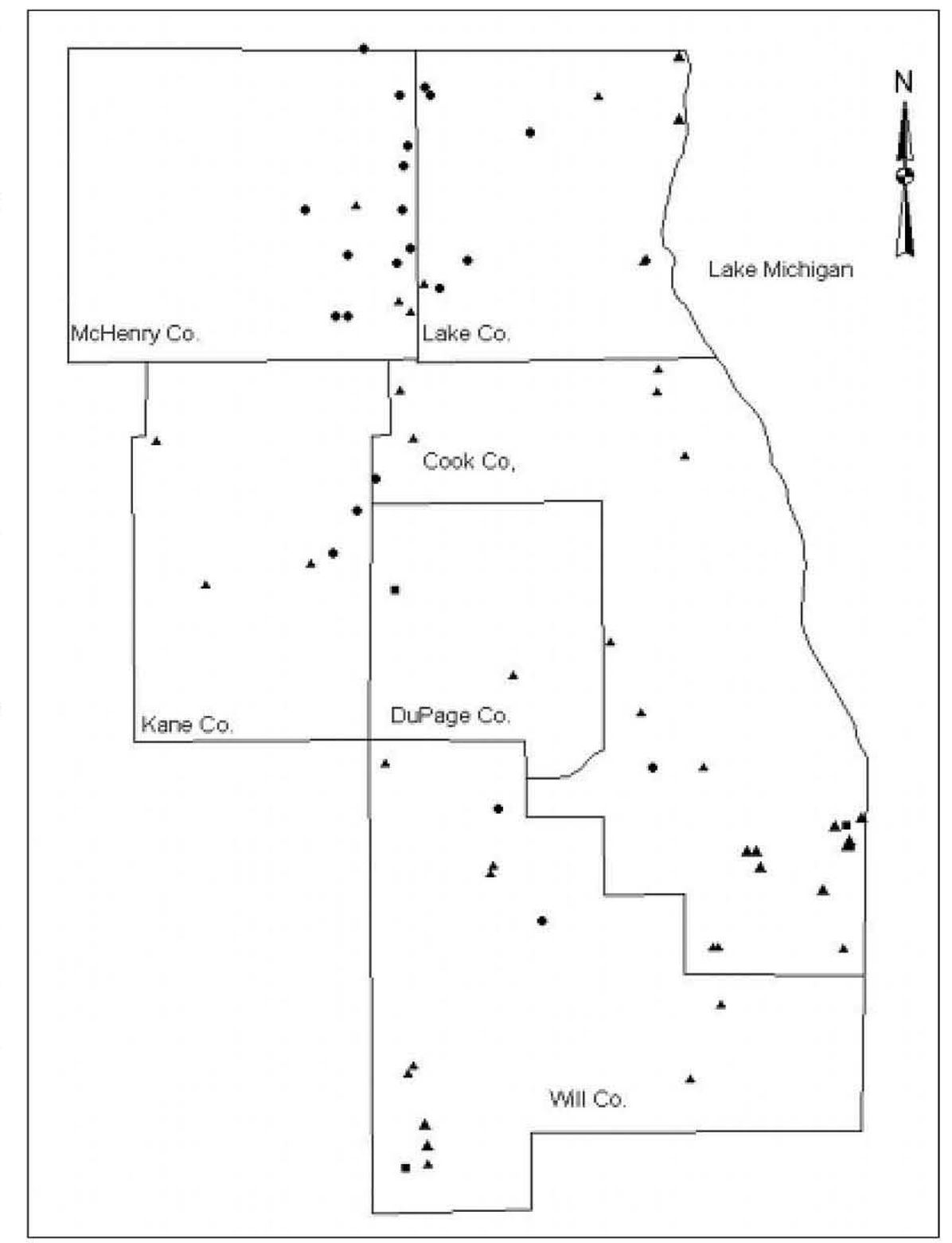

Figure 1. Locations of Illinois Natural Areas Inventory prairie $(\boldsymbol{\Delta})$, savanna ( $\mathbf{\square})$ and wetland (O) natural areas from which sampling data were analyzed. Some sites represent multiple communities. 


\section{Methods}

To ensure that our analyses represented naturally occurring vegetation that had not been substantially altered by human intervention, we used data collected by the Illinois Natural Areas Inventory in 1976 (White 1978). This statewide survey sampled almost 100 groundlayer vegetation transects representing high-quality prairie, savanna and graminoid wetland natural areas identified in the Chicago region of Illinois (Figure 1). These remnants tend to be distributed either by chance or by local occurrences of specialized habitats, such as sand-and-gravel deposits or wetlands. The natural quality of each site was graded by the INAI based on its stage of plant succession following human-caused disturbance. In this system, Grade A vegetation was defined as stable or undisturbed, Grade B as late-successional following human disturbance, Grade $\mathrm{C}$ as heavily disturbed and mid-successional, and Grade D as very heavily disturbed early-successional
(White 1978). Some ecologists would assign late-, mid-, and early successional to Grades A, B, and C, respectively. The INAI used a natural community classification system based on xeric, dry, dry-mesic, mesic, wet-mesic, wet, and hydric soildrainage classes defined by the U.S. Department of Agriculture (White and Madany 1981), a method similar to that used by Dix and Smeins (1967). In addition, loam, sand, gravel, and dolomite soil substrates were used in combination with drainage modifiers to further define communities, such as "dry-mesic sand prairie." Loam, the finest texture, was considered typic and was not used as a modifier, such as a "dry-mesic (silt-, clay-, or sand-loam) prairie." The Chicago region INAI data also included a single sand shrub prairie and six black oak (Quercus velutina) sand savannas, which were defined by having $10-80 \%$ tree canopy cover. We included the shrub prairie and sand savanna data sets in our analysis, as well as wetland data sets collected from sedge meadow, gramioind fen, calcareous seep, calcareous floating mat, marsh and

Table 1. Number and grade of graminoid plant communities sampled in the Chicago region of northeastern Illinois. Zeros $(0)$ indicate that sampling data were unavailable.

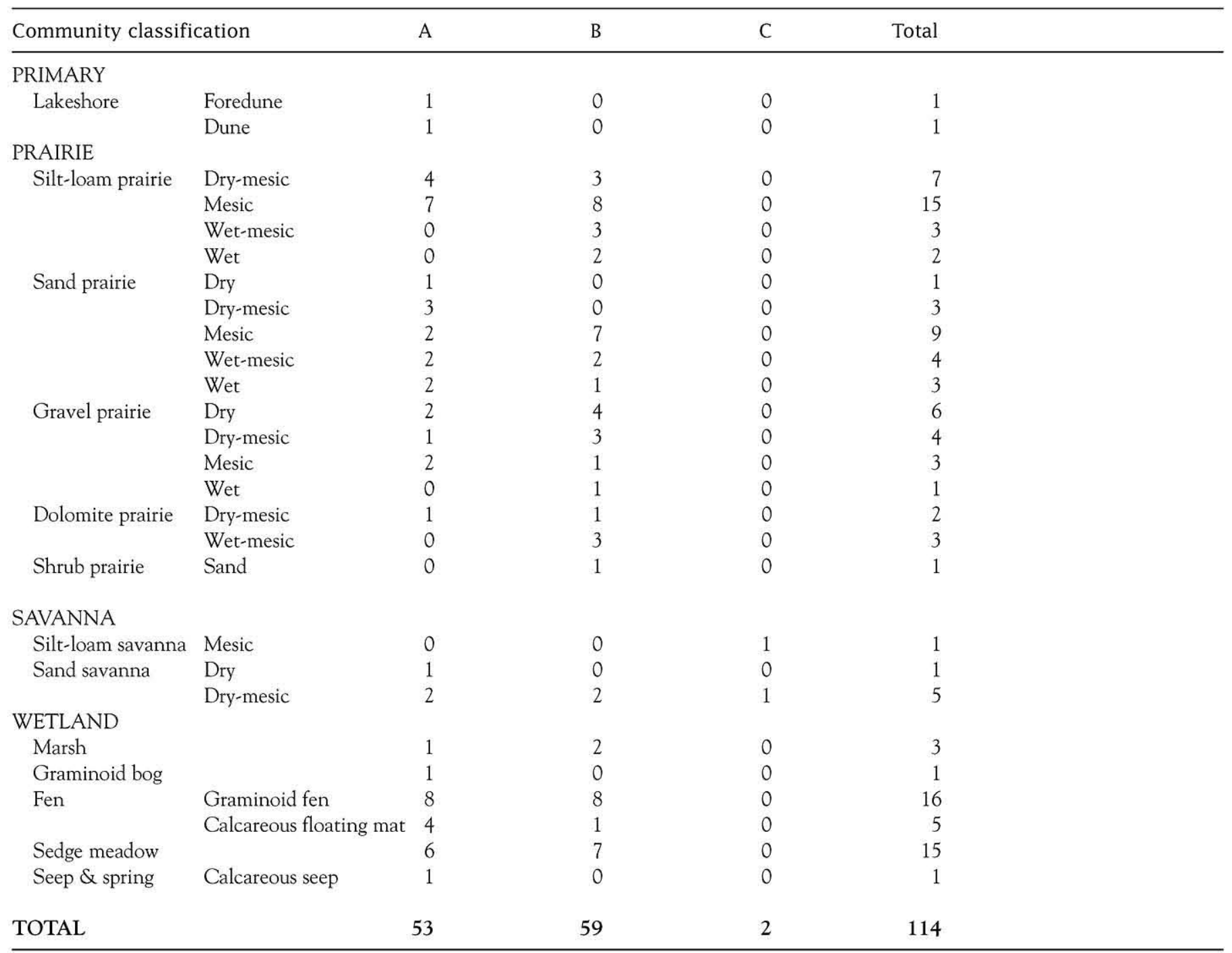



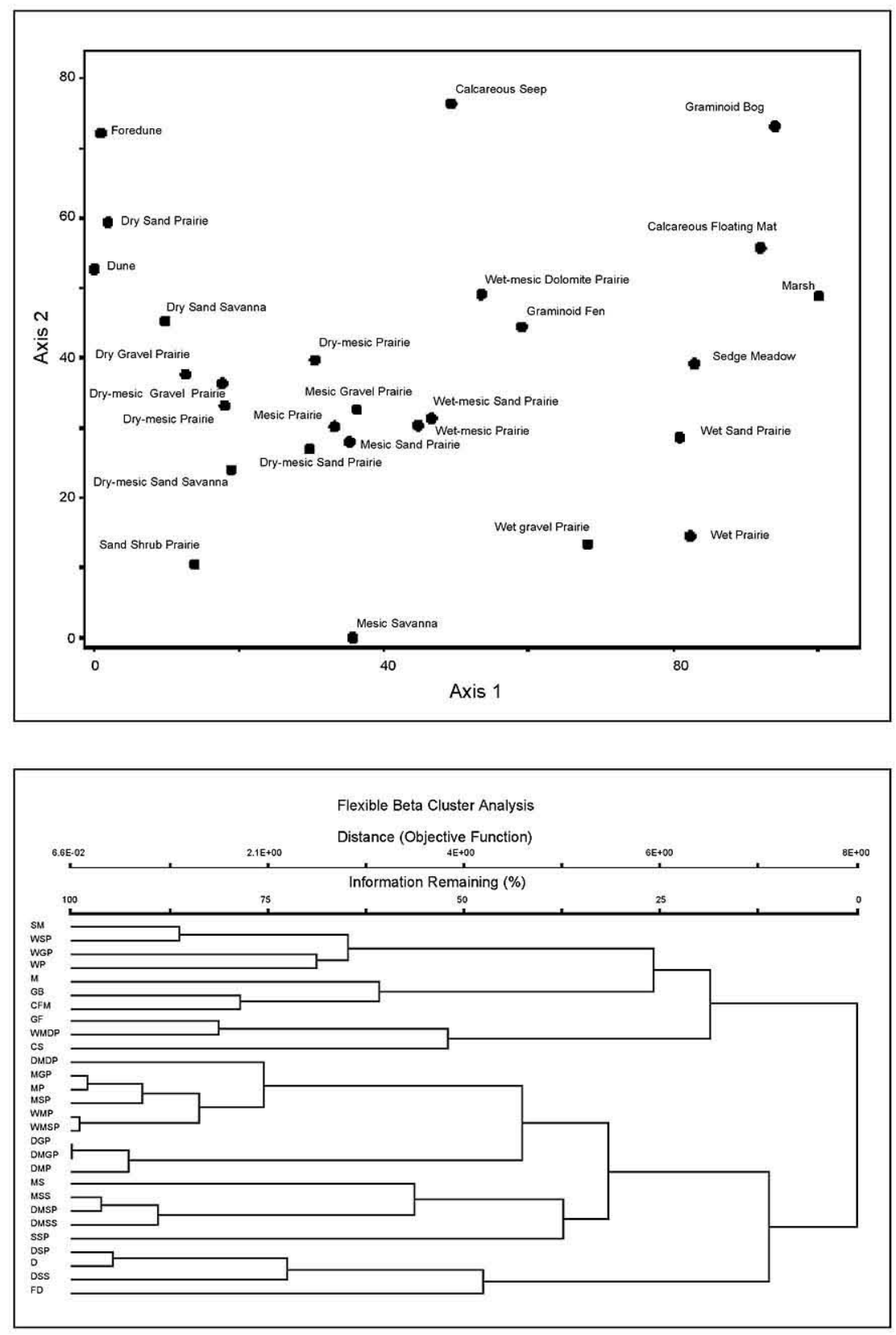

Figure 2. Non Metric Multi-dimensional Scaling ordination (upper) and Flexible Beta Cluster Analysis (lower) of Chicago region prairie and wetland vegetation. NMS: $<5 \%$ of 20 random runs with stress < observed stress for a two-dimensional solution; cumulative $\mathrm{r}^{2}$ for coefficient of determination between ordination distances and original distances $=0.771$ ). Flexible Beta: < $5 \%$ chaining.

graminoid bog vegetation. Nomenclature follows Plants of the Chicago Region (Swink and Wilhelm 1994).

The INAI usually sampled Grade A or B sites, using 20 to 30 circular $0.25-\mathrm{m}^{2}$ plots randomly distributed along transects within natural community types. We re-sampled the Chicago region sites in 2001-2003 by re-surveying original transect locations that had been mapped on 1:7,920 scale aerial photos. Our sampling indicated that many vegetation types had deteriorated over time with fire exclusion (Bowles and Jones 2004), but our data had more precise identification of difficult graminoid species. As a result, we used the 1976 data as the reference for undisturbed composition, and our data to correct for dominant grasses and sedges that were identified to the genus level in 1976. We also added recent data from a single foredune transect, as well as from six transects in INAI wet prairie stands that were not originally sampled, resulting in 103 data sets used for this study (Table 1). Each sampling data set was organized into a species by plot matrix from which species frequencies were calculated. These frequencies were then averaged across the replicate data sets for each community type and entered in a new matrix used for ordination and classification analysis. Seven rare habitat types (foredune, dune, dry sand prairie, dry sand savanna, sand shrub prairie, graminoid bog and calcareous seep) were represented by single data sets in this average matrix. Consequently, they would tend to have comparatively low total richness and unreplicated estimates of average species frequencies-factors that could affect subsequent analyses.

Community types were ordinated using Non-metric Multi-dimensional Scaling (NMS) with mean species frequencies as metrics and a Sorenson (Bray-Curtis) distance measure on PCORD (McCune and Mefford 1997). They were also clustered on PC-ORD using Ward's method with a Relative Euclidean distance measure. The soil moisture classes assigned to each community, as well as substrate types, allowed a direct gradient analysis of the ordination and avoided the circularity that otherwise would have resulted from interpreting species composition from a species-based classification. To assess species distribution across the moisture gradient, mean species frequencies from each community were averaged within each of the six moisture classes. Communities were assigned to these classes based on their alignment on the first ordination axis. Sand shrub prairie data were combined with dry-mesic prairie data, graminoid fen and calcareous seep data were averaged with wet-mesic prairie data, sedge meadow data were averaged with wet prairie data, and graminoid bog, marsh and calcareous floating mat data were averaged as hydric data. We also used Indicator Species Analysis (Dufrene and Legendre 1997) on PC-ORD to determine abundance of indicator species for different soil moisture classes, with a Monte Carlo test of significance at $\mathrm{P}<0.05$ with 1,000 runs.

Total species richness was taken from each original transect data set to avoid inflated values caused by pooling replicate transects. This measure represents an estimate of species richness based on the species accumulation curve for each transect. There was no significant variation $(\mathrm{F}=0.74, \mathrm{P}=$ 
$0.592)$ in sample size among soil moisture classes in this study $(\overline{\mathrm{x}}=21.87 \pm 0.41$ se plots/transect $)$, which would avoid bias in this estimate of richness. From the same data, we also calculated the average number of native species sampled per 0.25 $\mathrm{m}^{2}$ plot, which is a scale-dependent measure of $\alpha$ diversity, or species density. We then used ANOVA in a general linear model to test whether these metrics differed across the INAI soil moisture gradient classes described above, and also whether these values differed between Grade A and B data sets. We used two approaches to assess whether species distribution patterns fit the niche-based model of Brown (1984). We first used linear regression to test whether frequencies of species averaged across all communities in which they occurred were dependent upon their niche breadth, (i.e., the number of communities they occupied). We conducted this analysis using all communities, as well as a subset from which unreplicated rare communities had been eliminated.

In the second analysis, we tested whether rare species had more narrow niche breadths than common species. For this test, we defined rare species as having less than $10 \%$ average frequency ( $\mathrm{N}=282$ species) and common species as having greater than $20 \%$ frequency $(\mathrm{N}=142)$, and calculated species niche-breadths for these groups as the mean number of communities occupied. We used these arbitrary thresholds for rare and common, because average plot frequency $(\overline{\mathrm{x}}=11.5 \%$ \pm 15.4 std. dev.) for all species fell between these values. We also compared niche breadth and frequency between graminoid and woody species groups in both rare and common categories. Woody vegetation occurrences were too infrequent for a statistical comparison.

\section{Results and Discussion Community Gradients}

The first and second NMS ordination axes contained more information than expected by chance, with the first axis accounting for more than three times as much variation and corresponding to the INAI soil moisture categories (Figure 2). The dry extreme of the ordination consisted of vegetation with low first axis scores. Foredune, dry sand prairie, and dune vegetation had the lowest scores, while dry sand savanna and dry gravel prairie tended to separate by higher first axis scores and lower second axis scores. Hydric vegetation, represented by calcareous floating mat, marsh and graminoid bog, had the highest first axis scores, and also separated from sedge meadow and wet prairie vegetation by higher second axis scores. Mesic and wet-mesic prairies were centrally located, with intermediate first axis scores, while dry-mesic prairies and dry-mesic savanna had lower first axis scores. Calcareous seep and sand shrub prairie had extremely high and low second axis scores, respectively. Ward's cluster analysis corresponded closely to the NMS ordination (Figure 2). With about 50\% information retained, six cluster groups had $77 \%$ correspondence to our a priori assignment of communities into six INAI drainage classes. With about $25 \%$ information remaining, two cluster groups corresponded to wetland and upland vegetation categories. Our hydric and wet prairie drainage classes formed separate groups in the wetland category. Among the upland cluster groups, one included five of the six communities assigned to the dry drainage class. Our drymesic and wet-mesic communities were more divergent between multiple cluster groups. Subgroups representing graminoid fen, calcareous seep and wet dolomite prairie, as well as graminoid bog, calcareous floating mat and marsh also corresponded to their separations on the second NMS axis. The INAI classified calcareous floating mat differently-as a type of fen.

Ordination of Chicago region prairie and wetland plant communities suggests that a soil moisture gradient is the strongest environmental factor affecting the distribution of this vegetation, which supports the one-dimensional species distribution model of Curtis (1959). The overriding importance of drainage is also shown by the clustering of different substrates within similar moisture classes. However, the soil moisture gradient is also linked with substrate and topographic effects. Dry sites are primarily on sand or gravel substrates, which are easily drained, especially on slopes, while hydric sites usually occupy low landscape positions and tend to be strongly organic because water saturation retards decomposition. Vegetation alignment on the second NMS ordination axis could reflect substrate effects, such as greater alkalinity and calcium content in fen, dolomite prairie and calcareous seep vegetation (Bowles and others 2005b). Other secondary effects are less clear, but could include differences in organic and nutrient content among sand, gravel and loam soils (Bowles and others 2005a). Such differences would support contentions that substrate effects are important in understanding multivariate vegetation patterns (Whitford 1958, Nelson and Anderson 1982, White and Glenn-Lewin 1984, Faber-Langendoen and Maycock 1994, Corbett and Anderson 2001). Because our data represent drainage and substrate classes that lack exact environmental measures, specific effects are unknown. However, our data appear to be most strongly influenced by drainage as they represent broad hydrological gradients within different substrate typeseffects that are rarely detected in other vegetation studies.

\section{Species Distribution Species Richness and Spatial Abundance}

More than 450 species were sampled across all communities. Graminoid species represented $22 \%$ of these species, forbs $68 \%$, and woody species $10 \%$. As found by Curtis (1959) and by Dix and Smeins (1967), species richness was lowest at the dry and wet extremes of the moisture gradient, with average total richness exceeding 40 species in mesic and wet-mesic habitat (Figure 3). Mean plot species richness corresponded similarly $(\mathrm{F}=8.99, \mathrm{P}<0.001)$, with highest values in mesic and wet-mesic habitats, which exceeded ten species per 0.25 $\mathrm{m}^{2}$. As a result, total richness and plot species richness were significantly correlated $(\mathrm{r}=0.556, \mathrm{P}<0.001)$. This tendency for greater species richness in mesic habitat is apparently regulated by multiple factors, including levels of biomass, nutrients and competition, as well as the pool of species available to colonize this habitat (Grace 2001). Grade A prairies had 
higher total richness $(\mathrm{F}=4.91, \mathrm{P}=0.029)$ and higher plot species richness $(\mathrm{F}=12.0, \mathrm{P}<0.001)$ than Grade $\mathrm{B}$ prairies. This indicates that species richness can be an important factor in ranking vegetation quality (Bowles and Jones 2006).

Most species were rare at the landscape level, with 33\% occurring in single communities and $70 \%$ found in less than five communities (Figure 4). Most species were also infrequent within communities with $50 \%$ occurring at less than $10 \%$ average plot frequency and $70 \%$ occurring at $20 \%$ or less frequency. There was a significant positive correlation $(\mathrm{P}<$ $\left.0.001, r^{2}=0.054\right)$ between average species frequencies and their niche breadth (measured by the number of communities occupied) across all communities and a stronger correlation $\left(\mathrm{P}<0.001, \mathrm{r}^{2}=0.182\right)$ across communities represented only by multiple replicates.

Niche differences also occurred between rare and common vegetation (Table 2). Among all species, common species had greater niche breadth than rare species. There was no difference in niche width between common or rare graminoid and forb species. Thus, few species were widely distributed, and species that were more frequent within communities had broader niche distributions, fitting the niche-based regional species distribution model of Brown (1984). Collins and Glenn (1991), using data from Betz and Lamp (1989), verified this same pattern. However, because their site data was based on species lists, within-habitat species frequencies were not available to test whether widespread species also were more frequent within habitats.) Graminoid species represented only $25 \%$ of all common species but averaged greater plot frequency than forbs (Table 2). This indicates that prairies and graminoid wetlands tend to be dominated by comparatively few graminoid species that occur at relatively high frequencies, but that species richness is dependent upon a larger number of lessfrequent forbs. Shrubs were the most infre-

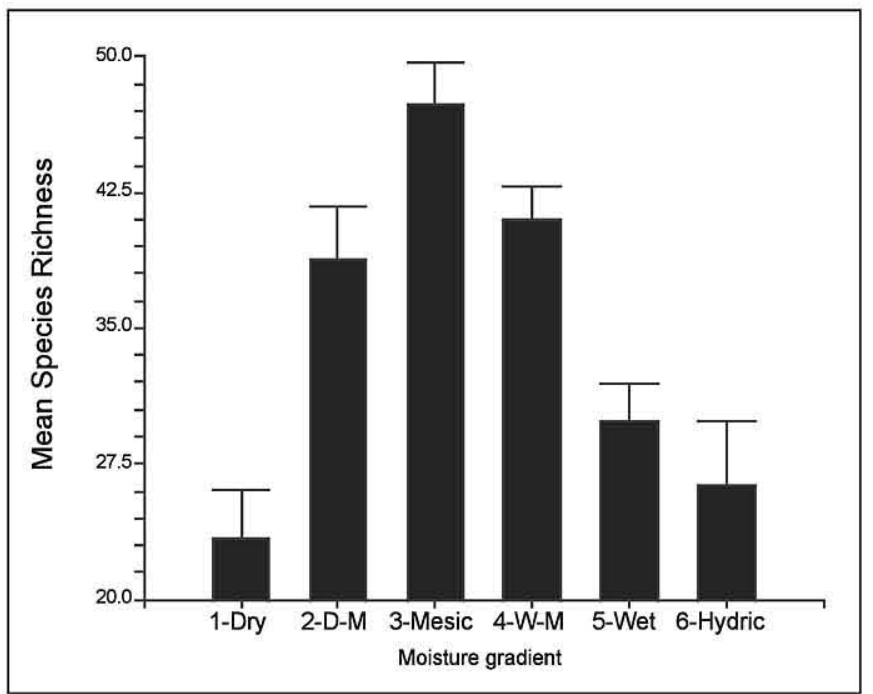

Figure 3. Unimodal distribution of species richness across a soil moisture gradient of prairie and wetland plant communities. ANOVA: $\mathrm{P}<0.001$, Duncan's multiple range test: Dry, Wet and Hydric differ from Dry-mesic, Mesic and Wet-mesic at $\mathrm{P}<0.05$.

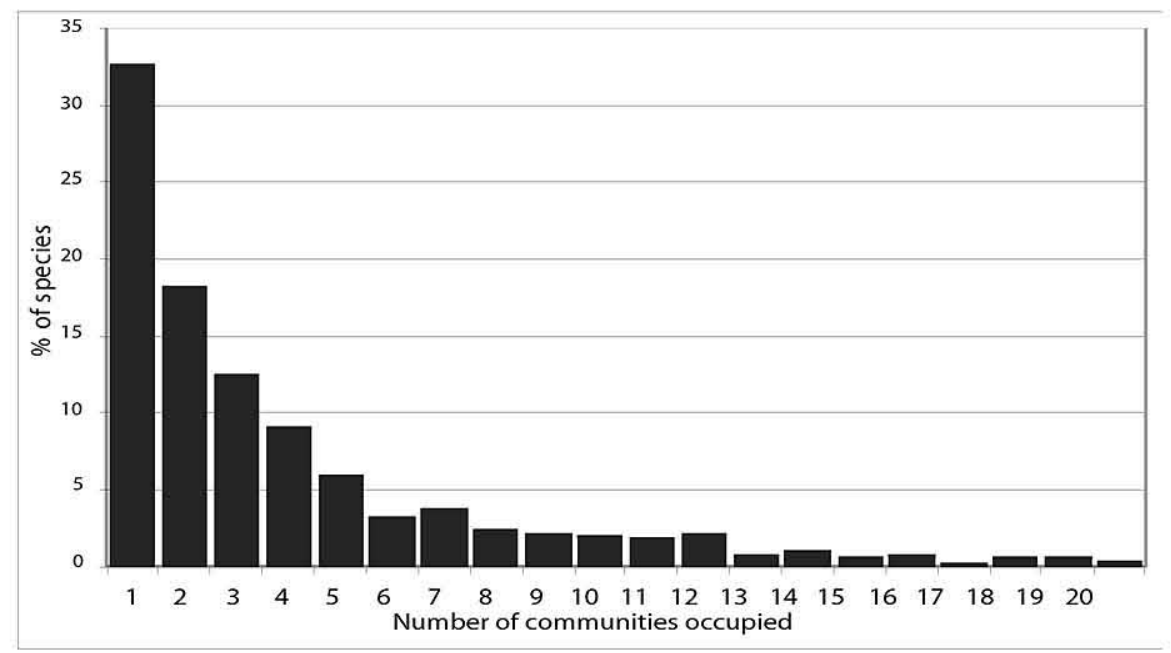

Figure 4. Distribution of species among high-quality prairie and wetland plant communities.

Table 2. Summary of statistical tests of effects of soil moisture gradient and INAI grade on species richness, and effects of habit (graminoid vs forb) on niche width and on frequency of plants occurring at $>\%$ plot frequency.

\begin{tabular}{llll}
\hline Variable (test) & Effect & Test statistic & Probability \\
\hline $\begin{array}{lll}\text { Total species richness } \\
\text { (factorial ANOVA, GLM) }\end{array}$ & Soil moisture gradient & $\mathrm{F}=12.29$ & $<0.0001$ \\
& $\begin{array}{l}\text { Grade (A vs B) } \\
\text { Interaction }\end{array}$ & $\mathrm{F}=4.91$ & $=0.0289$ \\
Plot species richness & Soil moisture gradient & $\mathrm{F}=2.87$ & $<.0180$ \\
(factorial ANOVA, GLM) & Grade (A vs B) & $\mathrm{F}=12.00$ & $=0.0001$ \\
& Interaction & $\mathrm{F}=1.79$ & $=0.1218$ \\
Niche width (Mann-Whitney) & Graminoid vs forb & $\mathrm{Z}=-.4741$ & $=0.6354$ \\
Frequency (Mann-Whitney) & Graminoid vs forb & $\mathrm{Z}=3.2887$ & $=0.0010$ \\
\hline
\end{tabular}


quent components of these communities, with only 46 species sampled, 5.38 ( $\pm 0.87 \mathrm{se})$ species occurrences per community, an overall average frequency of $10.24 \%( \pm 2.51 \mathrm{se})$ and an average niche width of $3.08( \pm 0.37 \mathrm{se})$.

\section{Species Distribution in Relation to Soil Moisture Classes}

Dominant graminoid and forb species showed strong individualistic but overlapping distribution patterns along the soil moisture gradient (Appendices I and II). Individual species distributions by plant community are in the appendices. These unique distributions along a moisture gradient are consistent with Curtis's findings (1959) that species form a vegetational continuum. This pattern is most clear with forbs. Graminoid species tend to form a hierarchical nested continuum, which would be expected when dominant species, such as grasses, are present (Collins and others 1993). Our lack of data from intermediate drainage positions (e.g., midway between dry and drymesic) as well as the potential for use of dominant grasses to help identify moisture classes may affect this distribution. Nevertheless, dominant prairie grasses are well known as indicators of soil drainage characteristics because they are organized by $\beta$-level competition (Parrish and Bazzaz 1979). Our data indicate that dry to dry-mesic habitats tend to be dominated by graminoid species with broad niches, while wet-mesic to hydric habitats tend to have dominants with more narrow niches. Upland sites are also dominated by prairie grasses, while sedges and grasses dominate wetlands. Indicator Species Analysis (Dufrene and Legendre 1997) produced a total of 89 species $(<20 \%$ of all species) that were significant indicators (at $\mathrm{P} \leq 0.05$ ) of one of the six moisture gradient categories. These species were also unevenly distributed $\left(X^{2}=56.97, \mathrm{P}<\right.$ 0.001 ) with $66 \%$ representing hydric or mesic habitats, $26 \%$ representing wet or wet-mesic habitats, and $8 \%$ representing dry or dry-mesic habitats. More than half $(54 \%)$ of the indicator species were common species (i.e., with $>20 \%$ plot frequencies in at least one community) and were primarily forbs. As indicated by Corbett and Anderson (2001), the tendency for dominant species to be widespread prevents them from being good indicators of specific habitats. The rarity of most species also precludes them from being sampled or detected as potential indicators, a condition observed for modal species by Curtis (1959).

\section{Vegetation Types}

\section{Dry Habitats: Dune, Prairie, and Savanna}

Dry habitats are restricted to somewhat excessively drained gravel and sand substrates, with sand habitats occurring primarily along Lake Michigan. Schizachryium scoparium was dominant or co-dominant across all dry habitats. However, Sorghastrum nutans and Stipa spartea were abundant and absent only from dunes. Other dominant grasses were more restricted to specific substrates. These included Ammophila breviligulata on fordune habitat, Calamovilfa longifolia in dry sand prairies, and Koeleria cristata on sand dunes. Dry gravel prairies differed by having Sporobolus heterolepis as a co-dominant grass, with
Bouteloua curtipendula an important secondary species. Dry sand savannas had Stipa spartea as a co-dominant. Carex pennsylvanica also reached its greatest abundance in dry-sand savanna.

No single forb species was most abundant across all dry habitats, although Solidago nemoralis was present at comparatively high frequencies throughout. Solidago nemoralis and Artemisia caudata were the most abundant forbs on foredunes, Coreopsis lanceolata and Artemisia caudata in dry sand prairie, Liatris aspera and Arenaria stricta on dunes, Helianthus occidentalis and Euphorbia corollata in dry sand savanna, and Petalostemum purpureum and Aster laevis in dry gravel prairie. Shrubs were more restricted in distribution, and were not sampled in foredunes. The trailing shrubs Arctostaphylos uvaursi and Juniperus horizontalis were dominant and co-dominant species on dune habitats. Rosa blanda was the most abundant shrub in dry sand prairie, while Rosa carolina was the leading shrub in dry sand savanna (with Arctostaphylos uva-ursi and Quercus velutina) and in dry gravel prairie (with Amorpha canescens). Some areas of the Lake Michigan dunes had an open canopy of white pine (Pinus strobus) in the early 1900s (Pepoon 1927), probably in association with trailing shrubs, which might have allowed their classification as a pine forest or pine barrens. The occurrence of Quercus velutina in groundlayer vegetation in sand savanna may represents post-fire sprouting from tree bases, as these sites had high fire frequencies at the time of the INAI.

\section{Dry-mesic Habitats: Prairie and Savanna}

Dry-mesic habitats occur across a wide range of well-drained substrates, and consequently they support many different dominant species. Among grasses, Andropogon scoparius and Sorghastrum nutans were dominant across most habitats, with greater abundance of Sporobolus heterolepis and Stipa spartea in both gravel and loam prairies. Andropogon gerardii was dominant in sand shrub prairie and present in lower frequencies in other communities. Euphorbia corollata, Monarda fistulosa and Aster ericoides were the most widespread abundant forbs, but neither was most frequent in more that two habitats. Tradescantia ohiensis was the dominant forb in sand prairie and sand savanna, followed by Aster azureus in sand prairie and Viola sagittata and Helianthus divaricatus in savanna. Euphorbia corollata, Monarda fistulosa, and Liatris cylindracea were dominant forbs in gravel prairie, Aster ericoides and Monarda fistulosa in dolomite prairie, and Euphorbia corollata and Aster ericoides in loam prairie. In sand shrub prairie, Helianthus mollis and Polygonatum canaliculatum were the most frequent forbs. Amorpha canescens and Rosa carolina were the most common shrubs in most dry-mesic habitats, with Ceanothus americanus reaching secondary abundance in sand prairie. The shrubs Spiraea tomentosa and Rubus setosus were dominant species in sand shrub prairie. The blueberries Vaccinium angustifolium and Vaccinium pallidum were restricted to sand savanna, possibly due to presence of acid sand soils as well as partial shade tolerance. 


\section{Mesic Prairie Habitats}

Mesic prairie vegetation occupies moderately well-drained habitats. Andropogon gerardii, Sorghastrum nutans, and Sporobolus heterolepis were the most widespread dominant grasses in mesic prairie habitats, although Sporobolus heterolepis tended to be less abundant in sand prairies. Schizachyrium scoparium was subdominant in these habitats. No forb species were most important across all mesic habitats. Aster ericoides was the dominant forb in mesic loam prairie, followed in abundance by Allium cernuum, Silphium terebinthenaceum, and Ratibida pinnata. Pycnanthemum virginianum was the most frequent forb in mesic sand prairie, followed in abundance by Aster ericoides. Allium cernuum and Smilacina stellata were dominant forbs in mesic gravel prairie, with secondary abundance of Ratibida pinnata. Rosa carolina was the most abundant shrub in all mesic habitats. Cornus racemosa and Amorpha canescens were important secondary shrubs in loam and gravel prairie, while Rubus hispidus was also important in mesic sand prairie.

\section{Wet-mesic Habitats: Prairie, Calcareous Seep, and Graminoid Fen}

Wet-mesic prairie, seep, and fen communities are transitional between prairie and wetland habitats due to their imperfectly or somewhat poorly drained conditions. Dolomite prairie, seep and fen habitats are also strongly calcareous. As a result, wet-mesic habitats support both prairie and wetland species, as well as calcicolous species. The prairie grasses Schizachryium scoparium and Sorghastrum nutans were abundant across all habitats, reaching subdominance in sand prairie, while Andropogon gerardii was absent only from seep habitat, and was dominant or co-dominant in graminoid fen and loam prairie, respectively. The wetland species Carex pellita and Spartina pectinata dominated loam prairie, while Calamagrostis canadensis was the leading dominant in sand prairie. Carex haydenii and Deschampsia cespitosa dominated dolomite prairie, while Juncus brachycephalus dominated seep habitat with secondary dominance by Rhynchospora capillacea and Carex haydenii. Muhlenbergia glomerata and Carex sterilis were co-dominant in graminoid fen.

Among forbs, Pycnanthemum virginianum and Senecio pauperculus were dominant in wet-mesic sand prairie, Silphium terebinthinaceum and Fragaria virginiana in loam prairie, and Solidago ohioensis and Solidago riddellii in dolomite prairie. In graminoid fen, Solidgo ohioensis and Pycnanthemum virginianum were the most frequent forbs. The most abundant forbs in calcareous seep vegetation were Lobelia kalmii and Solidago uliginosa, although Silphium terebinthinaceum was not infrequent. There were few abundant shrubs in wet-mesic habitats. Cornus racemosa was most abundant shrub in loam prairie, but was less frequent than Potentilla fruticosa in graminoid fen and calcareous seep habitat. Rubus hispidus was the leading shrub in wet-mesic sand prairie, while Salix glaucophylloides was the most frequent shrub in dolomite prairie.

\section{Wet Habitats: Prairie and Sedge Meadow}

Wet prairie and sedge meadow vegetation occupy poorly drained habitats, and had strong similarity among their dominant graminoid species. Calamagrostis canadensis and Carex stricta were abundant in all habitats, with the former being the leading dominant in all wet prairies and secondary to Carex stricta in sedge meadows. Carex pellita and Spartina pectinata were co-dominant in wet prairies, but were absent or infrequent in sedge meadows. Only Convolvulus sepium was a codominant forb in both habitats. Dryopteris thelypteris and Lycopus uniflorus were the most frequent forbs in wet sand prairie, while Solidago gigantea, Convolvulus sepium and Galium obtusum were dominant forbs in wet gravel prairie, and Aster simplex and Lycopus americanus most frequent in wet prairie. Pycnanthemum virginianum was the leading forb in sedge meadow, followed by Eupatorium maculatum, Lycopus virginicus, and Dryopteris thelypteris. Shrubs were infrequent, with Salix interior the most important shrub species in wet prairie and Rosa blanda in sedge meadow.

\section{Hydric Habitats: Marsh, Floating Mat and Bog}

Hydric habitats are very poorly drained with the water table at or above the surface the greater amount of the time. Marsh vegetation shared only a single dominant species with prairie vegetation-Calamagrostis canadensis. Co-dominant graminoid species in marshes were Carex lacustris, Typha latifolia, Typha angustifolia, and Carex lasiocarpa. The most abundant forbs were Scutellaria epilobiibolia, Lycopus virginicus, and Lysimachia thyrsiflora. Cornus stolonifera was the only frequent shrub in marsh vegetation. In calcareous floating mat vegetation, Carex lasiocarpa and Calamagrostis canadensis were the dominant graminoid species, while Scirpus validus and Carex aquatilis were also abundant. Lycopus virginicus, Lysimachia thrysiflora, Aster borealis and Dryopteris thelypteris were the most abundant forbs, while Salix pedicellaris, Spiraea alba, and Salix candida were dominant shrubs.

Graminoid bog vegetation had the most distinctive assemblage of species among all vegetation types and is known from only a single site. The dominant graminoid species was Eriophorum angustiolium, with minor representation of Muhlenbergia glomerata and Calamagrostis canandensis. Dryopteris thelypteris was the dominant forb, while Sarracenia purpurea, Lycopus virginicus, and Drosera rotundifolia were also abundant. Salix pedicellaris and Betula pumila were the most frequent shrubs.

\section{Summary and Conclusions}

Our ordination indicates that soil drainage is the primary environmental factor affecting the distribution of prairie- and graminoid-dominated wetland plant communities in the Chicago region. This vegetation supports multiple models that have been demonstrated in other studies of prairie vegetation. As established by Curtis (1959), plant species formed an individualistic distribution comprising a continuum. Graminoid species also formed a nested hierarchical continuum, a pattern 
expected for dominant species (Collins and others 1993). The overlapping distributions of these species allow characterization of communities based on their compositional differences across differing substrate and moisture classes. Common graminoid and forb species were also more abundant among communities than rare species, supporting the niche-based regional species distribution model of Brown (1984).

Species richness was greatest at the midpoint of the soil moisture gradient, which apparently represents optimum resources for a greater pool of species available to colonize these intermediate habitats. Most species were rare within and among communities, with less than $20 \%$ of all species significant indicators of moisture gradient categories. These species were not evenly distributed, with greater abundance in hydric and mesic habitats.

Species that are commonly thought of as comprising prairie vegetation occurred across the entire dry to hydric soil moisture gradient, but were better represented in dry than in wet or hydric habitats. Prairie grasses also appear to have broader niches in upland sites than dominant grasses or sedges in wetlands. Schizachryium scoparium was the dominant grass in dry and dry-mesic habitats, and was less abundant in mesic and wet-mesic habitats. Stipa spartea, Koeleria cristata, and Bouteloua curtipendula were most abundant in drier habitats. Sorghastrum nutans, Andropogon gerardii, and Sporobolus heterolepis were the most abundant grasses in mesic habitats, and were replaced by increasing abundances of Calamagrostis canadensis and Spartina pectinata in wet-mesic and wet habitats. These grasses, as well as some prairie forbs also extended into sedge meadow and graminoid fen, where they associate with wetland and calcicolous sedge and grass species. However, only Calamagrostis canadensis continued as an important grass in hydric habitats. Although some sedge species characterize upland habitats, many tend to become more abundant than grasses primarily in lower points of the soil moisture gradient. These species include Carex stricta, Carex haydennii and Carex pellita in wetmesic to wet habitats, Carex lacustris and Carex lasiocarpa in wet habitats, and Carex aquatalis in hydric habitats.

\section{Acknowledgments}

We thank the Illinois Department of Natural Resources Wildlife Preservation and Conservation-2000 funding programs, the Chicago District of the U.S. Army Corps of Engineers, CorLands, and the Chicago Wilderness and Illinois Conservation Foundation for administering USDA Forest Service and US Fish and Wildlife Service funds for this work. Staff of the Illinois Nature Preserves Commission, Illinois DNR, the Forest Preserve or Conservation Districts of DuPage, Cook, Kane, Lake, McHenry and Will counties, Lake Forest Open Lands, the Downers Grove Park District, and many private landowners and stewards provided much assistance and management data, as well as permission to visit sites. We also thank the Illinois DNR, as well as the original INAI staff, for providing original data, and Tim Bell, Christopher Dunn, Andrew Hipp, Jenny McBride, and John White for review, discussion or technical assistance.

\section{References}

Anderson, R.C. 1990. The historic role of fire in the North American grassland. Pages 8-18 in S. Collins and L. Wallace (eds.), Fire in North American tallgrass prairies. Norman: University of Oklahoma Press.

Anderson, R.C. and M.L. Bowles 1999. Deep-soil savannas and barrens. Pages 155-167 in R.C. Anderson, J.S. Fralish and J. M. Baskin (eds.), Savannas, barrens and rock outcrop plant communities of North America. Cambridge, U.K.: Cambridge University Press,

Betz, R.F. 1986. One decade of research in prairie restoration at the Fermi National Accelerator Laboratory (Fermilab), Batavia, Illinois. Pages 179-184 in G.K Clambey and R.H. Pemble (eds.), Proceedings of the Ninth North American Prairie Conference, Fargo, North Dakota:TriCollege University, North Dakota State University.

Betz, R.F. and and H.F. Lamp. 1989. Species composition of old settler siltloam prairie cemeteries. Pages 33-39 in T.B. Bragg and J. Stubbendieck (eds.), Proceedings of the Eleventh North American Prairie Conference. Lincoln, Nebraska: Univeristy of Nebraska Printing.

Betz, R.F., R. J. Lootens and M. K. Becker. 2000. Two decades of prairie restoration at Fermilab, Batavia, Illinois. Pages 20-30 in C. Warwick (ed.), Proceedings of the Fifteenth North American Prairie Conference. Bend, OR: Natural Areas Association.

Bliss, L.C. and G.W. Cox. 1964. Plant community and soil variation within a northern Indiana prairie. American Midland Naturalist 72:115-128

Bowles, M. and M. Jones. 2004. Long-term changes in Chicago region prairie vegetation in relation to fire management. Chicago Wilderness Joumal 2(2):7-16.

Bowles, M., L. Zettler, T. Bell and P. Kelsey. 2005a. Relationships between soil characteristics, distribution and restoration potential of the federal threatened eastern prairie fringed orchid, Platanthera leucophaea (Nutt.) Lindl. American Midland Naturalist 154:273-285.

Bowles, M., P.D. Kelsey and J.L. McBride. 2005b. Relationships among environmental factors, vegetation zones, and species richness in a North American calcareous prairie fen. Wetlands 25:685-697.

Bowles, M. and M. Jones. 2006. Testing the efficacy of species richness and floristic quality assessment of quality, temporal change and fire effects in tallgrass prairie natural areas Natural Areas Joumal 26 (in press).

Brown, J.H. 1984. On the relationship between abundance and distribution of species. American Naturalist 124:255-279.

Collins, S.L. and S.M. Glenn. 1991. Importance of spatial and temporal dynamics in species regional abundance and distribution. Ecology 72:654-664.

Collins, S.L., S.M. Glenn and D.W. Roberts. 1993. The hierarchical continuum concept. Joumal of Vegetation Science 4:149-156.

Corbett, E.A. and R.C. Anderson. 2001. Patterns of prairie plant species in Illinois landscape. Pages 177-181 in N.P. Bernstein and L.J. Ostrander (eds.), Proceedings of the Seventeenth North American Prairie Conference, Mason City, Iowa: North lowa Area Community College.

Crist, A. and D.C. Glenn-Lewin. 1978. The structure of community and envionmental gradients in a northern Iowa prairie. Pages 57-64 in D.C. Glenn-Lewin and R.Q. Landers, Jr. (eds.), Proceedings of the Fifth North American Prairie Conference. Ames, Iowa: Iowa State University.

Curtis, J.T. 1959. The Vegetation of Wisconsin. Madison: University of Wisconsin Press.

Dix, R.L. and FE. Smeins. 1967. The prairie, meadow, and marsh vegetation of Nelson County, North Dakota. Canadian Journal of Botany 45:21-58., 1967

Dufrene, M and P. Legendre. 1997. Species assemblages and indicator species: the need for a flexible asymmetrical approach. Ecological Monographs 67:345-366

Faber-Landendoen, D. and P.F. Maycock.1994. A vegetation analysis of tallgrass prairie in southern Ontario. Pages 17-32 in R.G. Wickett, P.D. 
Lewis, A. Woodliffe and P. Pratt (eds.), Proceedings of the Thirteenth North American Prairie Conference. Windsor, Ontario, Canada: Department of Parks and Recreation.

Fehrenbacher, J.B., D. Alexander, I.J. Jansen, R.G. Darmody, R.A. Pope, M.A. Flock, E.E. Voss, J.W. Scott, W.F. Andrews and L.J. Bushue. 1984. Soils of Illinois. Bulletin 778. Urbana-Champaign, Illinois: University of Illinois at Urbana Champaign College of Agriculture Experiment Station and Soil Conservation Service, S.S. Department of Agriculture.

Gleason, H.A. 1913. The relation of forest distribution and prairie fires in the middle west. Torreya 13:173-181.

1926. The individualistic concept of the plant association. Bulletin of the Torrey Botanical Club 53:7-26.

Grace, J.B. 2001. The roles of community biomass and species pools in the regulation of plant diversity. Oikos 92:193-207.

McBride, J.M and M.L. Bowles. 2001. Vegetation pattern of DuPage and Will counties at the time of European settlement. Pages 763-71 in C.E. Petersen (ed.), Proceedings of the Twelvth Northern Illinois Prairie Workshop. Glen Ellyn, Illinois: College of DuPage.

McCune, B. and M.J. Mefford. 1997. PC-ORD. Multivariate analysis of ecological data, Version 4. MjM Software Design, Gleneden Beach, Oregon.

Mittlebach, G.M., C.E. Steiner, S.M. Scheiner, R.L. Gross, H.L. Reynolds, R.B. Waide, M.R. Willig, S.I. Dodson and L. Gough. 2001. What is the observed relationship between species richness and productivity? Ecology 82:2381-2396.

Nelson, D.C. and R.C. Anderson. 1982. Factors related to the distribution of prairie plants along a moisture gradient. American Midland Naturalist 109:367-375

Packard, S. and C.F. Mutel. 1997. The tallorass restoration handbook for prairies, savannas, and woodlands. Washington D.C.: Island Press.

Parrish, J.A.D. and F.A. Bazaz. 1979. Organization of grassland communities. Pages 233-254 in J.R. Estes, R.J. Tyrl and J.N. Brunken (eds.), Grasses and grasslands: Systematics and ecology. Norman: University of Oklahoma Press.
Pepoon, H.S. 1927. Flora of the Chicago Region. Bulletin VIII. Chicago: Chicago Academy of Sciences.

Roberston, K.R. and M.W. Schwartz. 1994. Prairies. Pages 1-33 in The changing Illinois environment: critical trends. Technical report of the critical trends assessment project Volume 3: Ecological resources. Champaign, Illinois: Illinois Department of Energy and Natural Resources, Illinois Natural History Division.

Samson, F.B. and F.L. Knopf. 1996. Prairie conservation: Preserving North America's most endangered ecosystem. Washington D.C.: Island Press.

Swink, F. and G. Wilhelm. 1994. Plants of the Chicago Region. Indianapolis: Indiana Academy of Science.

Transeau, E.N. 1935. The prairie peninsula. Ecology 16:423-437.

Weaver, H.E. 1954. North American prairie. Lincoln, Nebraska: Johnsen Publishing Company.

White, J.A. and D.C. Glenn-Lewin. 1984. Regional and local variation in tallgrass prairie remnants of Iowa and eastern Nebraska. Vegetatio 57: 65-78.

White, J. 1978. Illinois Natural Areas inventory technical report, volume I. Survey methods and results. Urbana, Illinois: University of Illinois Department of Landscape Architecture and Rockford, Illinois: Natural Land Institute.

White, J. and M. Madany. 1981. Classification of prairie communities. Pages 169-171 in R.L. Stuckey and K.J. Reese (eds.), The prairie peninsula-in the "shadow" of Transeau. Proceedings of the Sixth North American Prairie Conference, Notes No. 15. Columbus, Ohio: Ohio Biological Survey.

Whitford, P.B. 1958. A study of prairie remnants in southeastern Wisconsin. Ecology 39:727-733.

Willman, H.B. 1971. Summary of the geology of the Chicago area. Circular 460. Urbana, Illinois: Illinois State Geological Survey. 


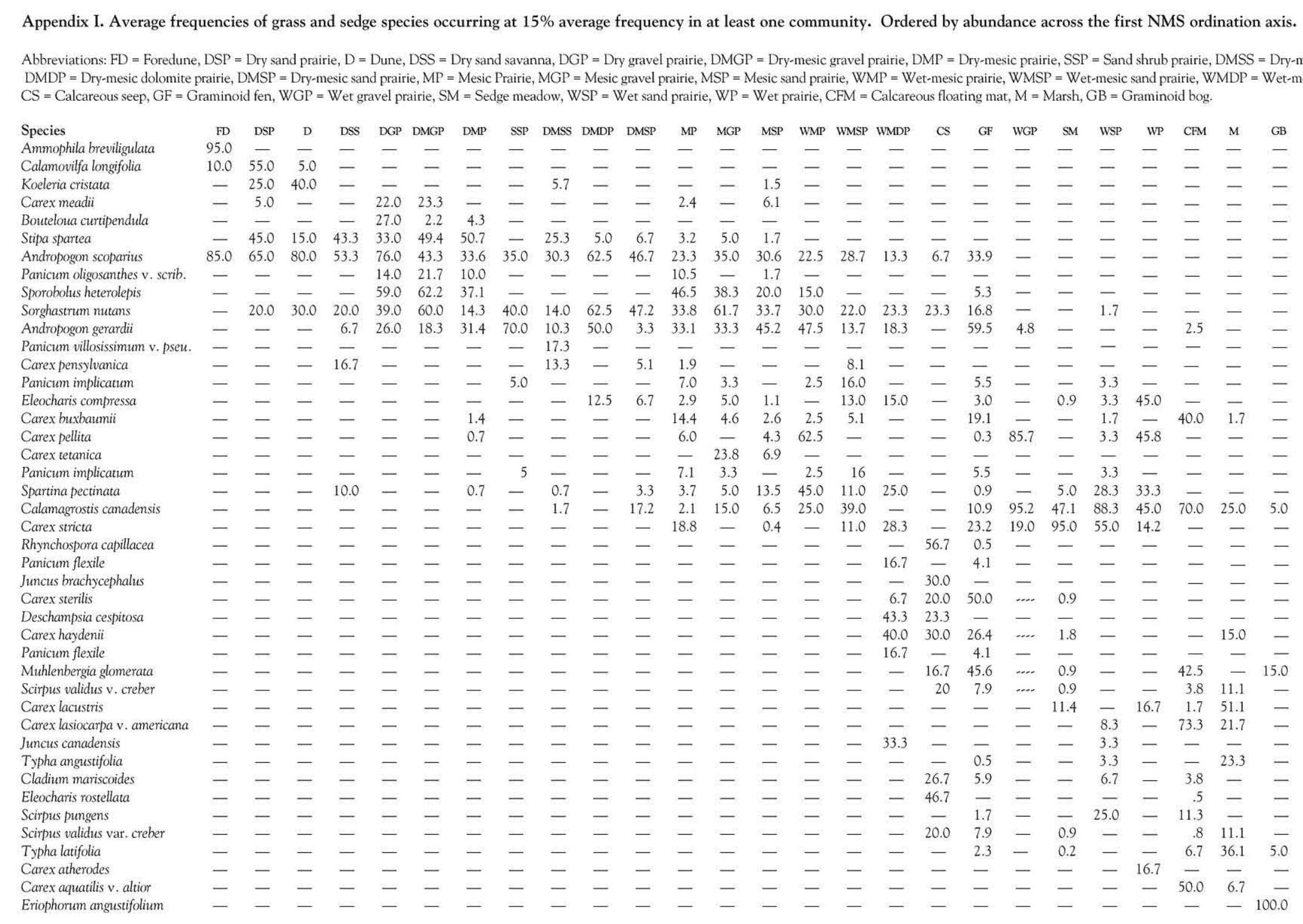




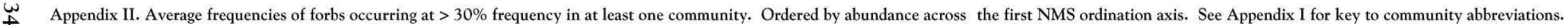

Species

$\begin{array}{llllllllllllllllllllllllllll}\text { FD } & \text { DSP } & \text { D } & \text { DSS } & \text { DGP } & \text { DMGP } & \text { DMP } & \text { SSP } & \text { DMSS } & \text { DMDP } & \text { DMSP } & \text { MP } & \text { MGP } & \text { MSP } & \text { WMP } & \text { WMSP } & \text { WMDP } & \text { CS } & \text { GF } & \text { WGP } & \text { SM } & \text { WSP } & \text { WP } & \text { CFM } & \text { M } & \text { GB }\end{array}$

Artemisia caudata

Coreopsis lanceola
Arenaria stricta

Helianthus occidentalis

Petalostemum purpureum

Liatris aspera

Solidago nemoralis

Euphorbia corollata

Smilacina stellata

Parthenium integifolium

Helianthus mollis

Potentilla simplex

Tradescantia ohiensis

Polygonatum canaliculatum

Anemone cylindrica

Aster azureus

Aster ericoides

Silphium terebinthinaceum

Eupatorizm altissimum

Allium cernutum

Liatris spicata

Monarda fistulo

Senecio pauperculus

Satureja arkansana

Solidago ohioensis

Aster laevis

Coreopsis tripteris

Lespedera capitata

Leseris cylindecen

Phlox pilosa

Physostegia virginiana

Senecio arreus

Spiraea tomentosa v. rosea

Thalictrum dasycarpum

Zizia atrea

Convolvulus sepium

Aster dumosus

Pycnanthemum virginiamum

- - - - - - - - - - - - - - - - - - - - - -

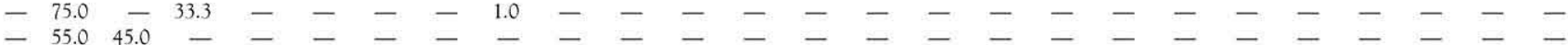

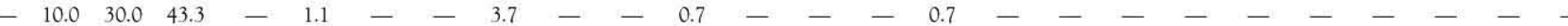

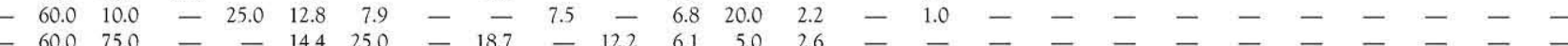

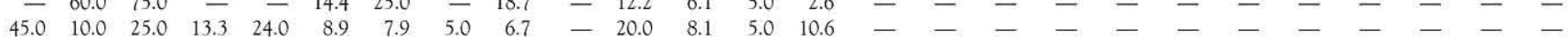

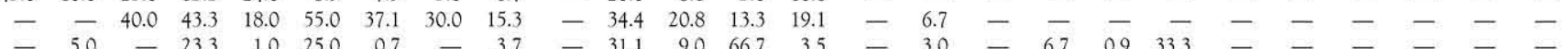

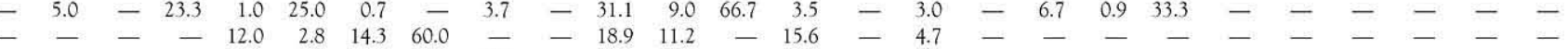

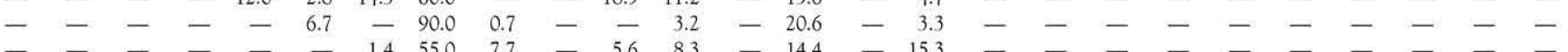

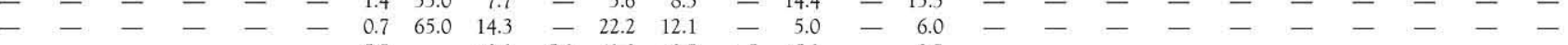

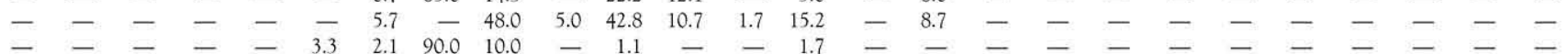

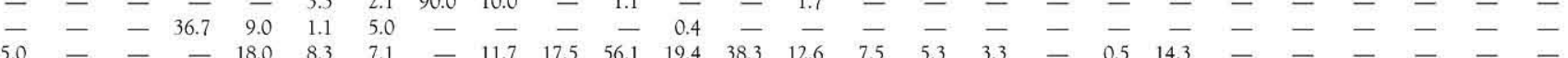

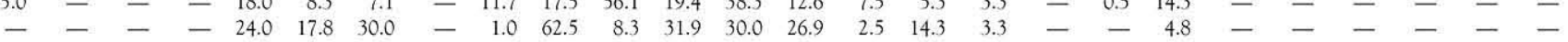

- - - $-\begin{gathered}- \\ -\end{gathered}$

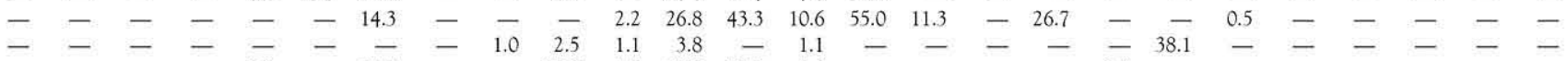

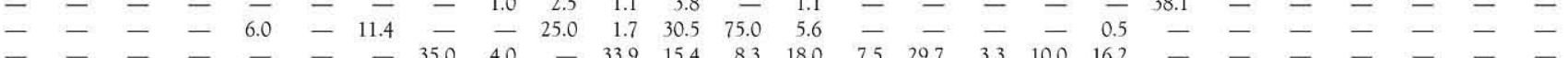

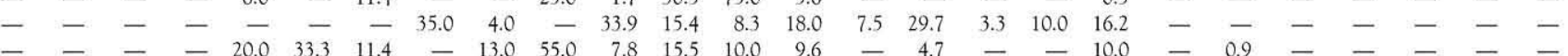

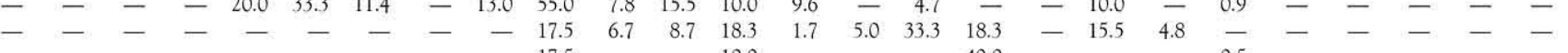

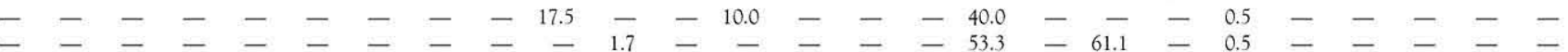

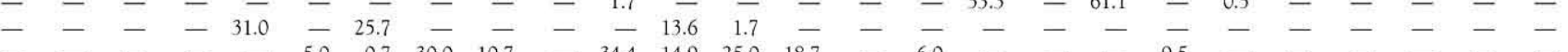

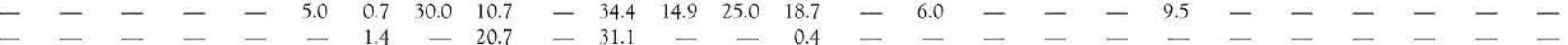

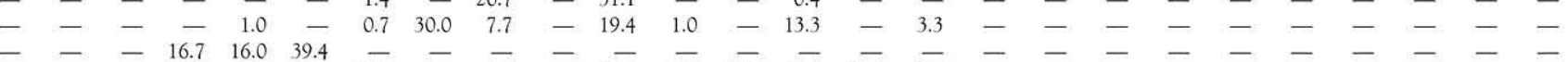

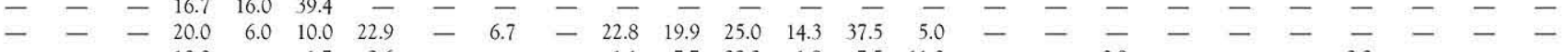

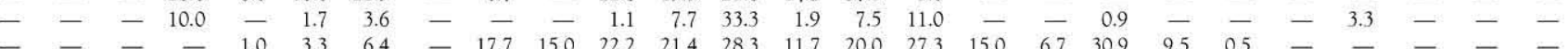

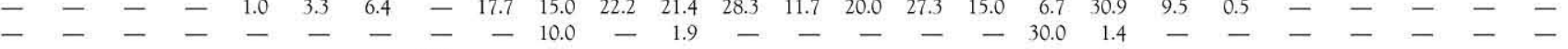

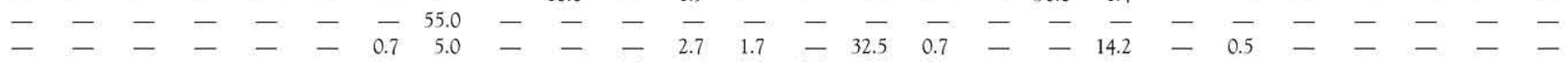

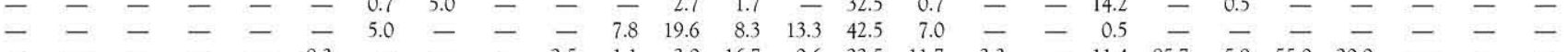

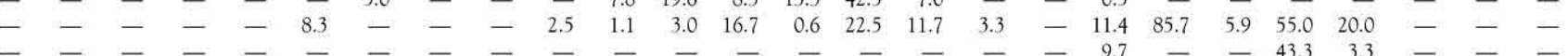

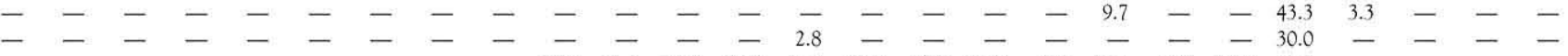

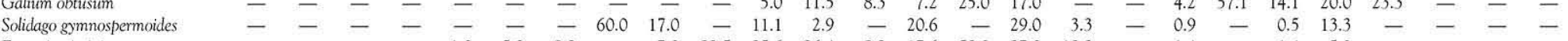

$\begin{array}{lllllllllllllllllllllllllllll}\text { Fragaria virginiana } & - & - & - & - & 1.0 & 5.0 & 9.3 & - & 7.0 & 32.5 & 25.6 & 26.4 & 8.3 & 17.6 & 50.0 & 27.0 & 13.3 & - & 1.4 & - & 1.4 & 5.0 & - & - & - & -\end{array}$

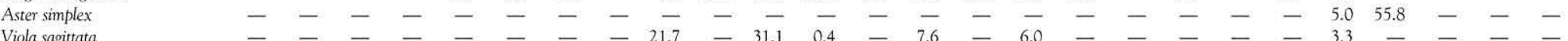

Campanula uliginosa $\quad-\quad-\quad-\quad-\quad-\quad-\quad-\quad-\quad-$

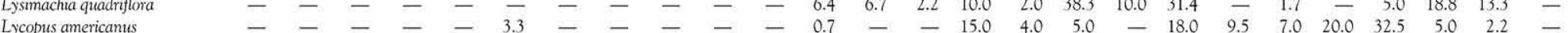

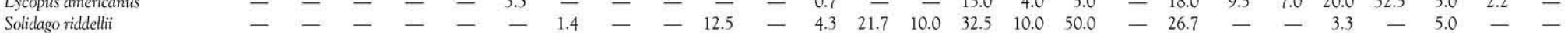

Lobelia kalmii

Solidago gigantea

Hypericum virginicum v. fraseri

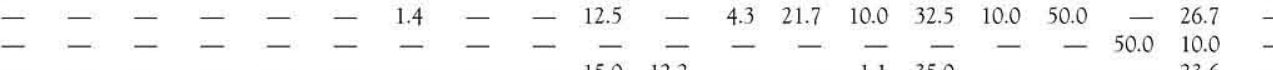

$\begin{array}{rrrrrr}7.0 & 20.0 & 32.5 & 5.0 & 2.2 & - \\ - & 3.3 & - & 5.0 & - & - \\ - & - & - & 1.3 & - & -\end{array}$

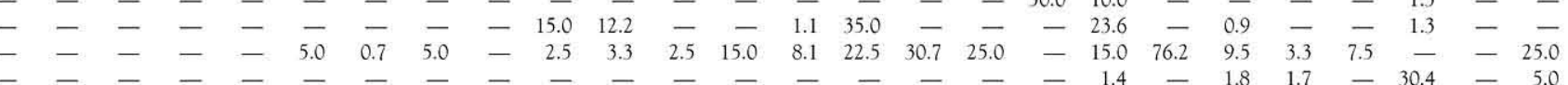


Appendix II, Continued. See Appendix I for key to community abbreviations.

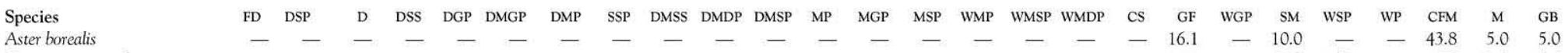
Aster borealis

Eupatorium maculatum

Scutellovia e ilobif

Dryopteris thelypteris v. pub.

Lycopus virginicus

Lysimachia thyrsiffora

Viola pallens

Potentilla palustris

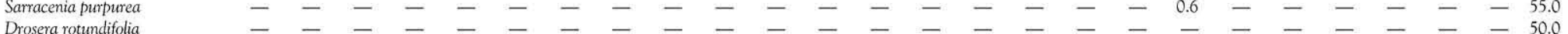

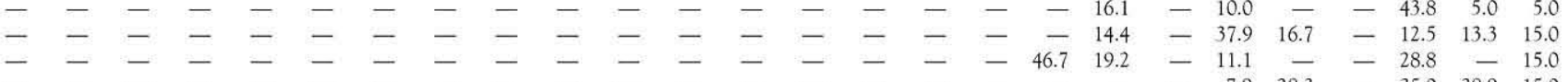

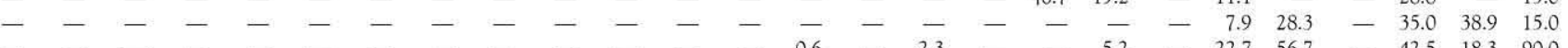

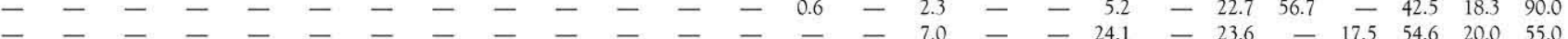

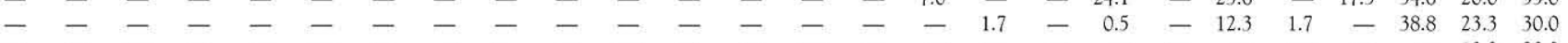

$---\quad-\quad-\quad-\quad-\quad-\quad-\quad-\quad-\quad-\quad-\quad-\quad-\quad-\quad-\quad-10.030 .0$

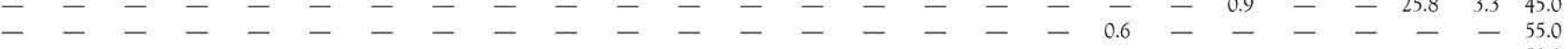

Appendix III. Average frequencies of woody vegetation occurring at 5\% frequency in at least one community. Ordered by abundance across the first NMS ordination axis. See Appendix I for key to community abbreviations.

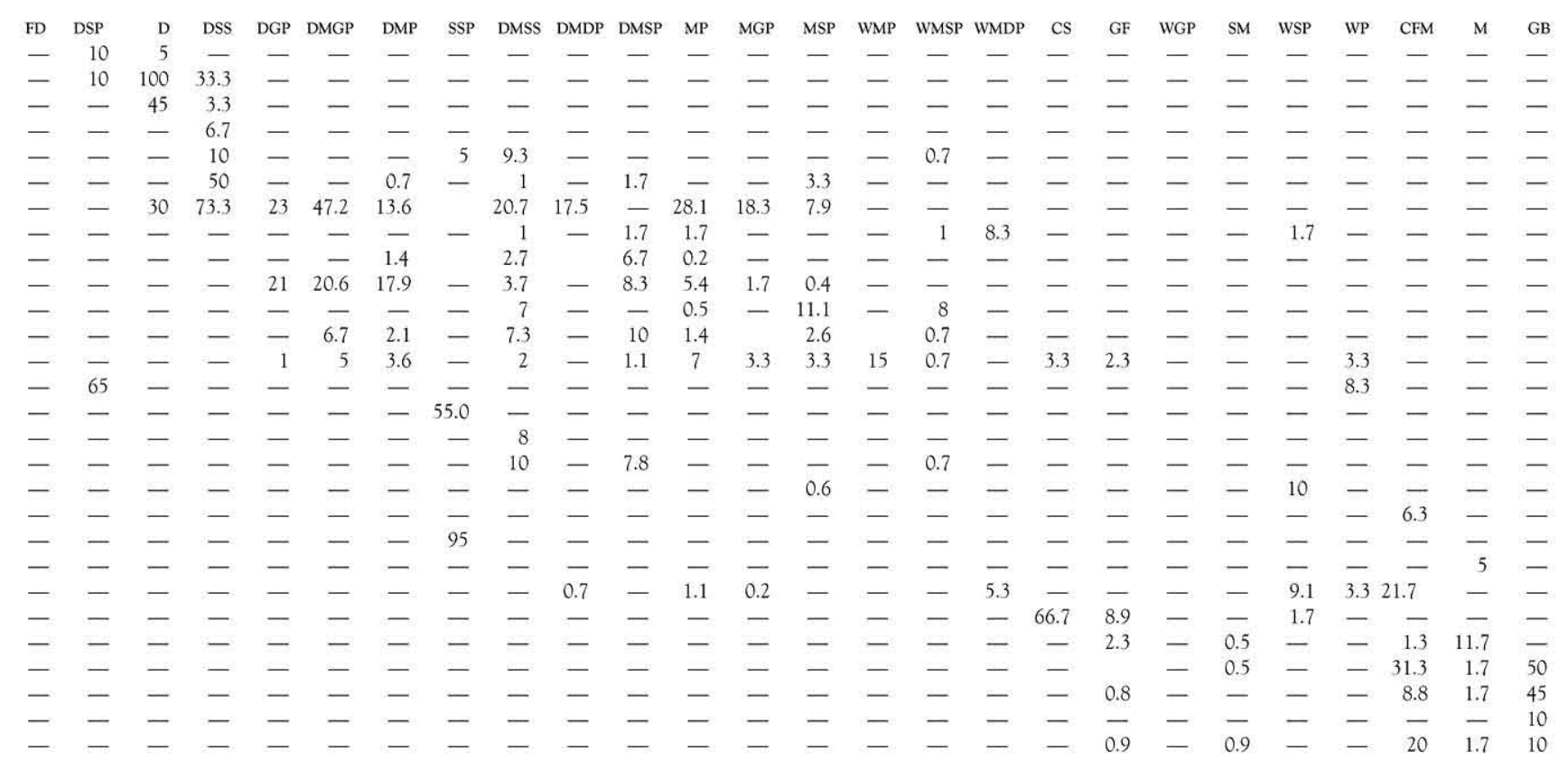

